\title{
The Effect of Organizational Culture on Motivation and Job Satisfaction and Its Impact on Organizational Citizenship Behavior (OCB) at the Office of PT. Permodalan Nasional Madani (PT.PNM) Garut Branch
}

\author{
Syamsul Hadi Senen ${ }^{1, *}$ Via Irhamny Az-Zahra ${ }^{2}$ \\ ${ }^{1}$ Universitas Pendidikan Indonesia \\ ${ }^{2}$ Universitas Pendidikan Indonesia \\ ${ }^{*}$ Corresponding author.Email: author@example.com (Alt+C)
}

\begin{abstract}
The purpose of this study is to determine the effect of organizational culture on work motivation and job satisfaction and its impact on organizational citizenship behavior (OCB) at PT. National Capital Madani (PNM) Garut Branch. The method used in this study is quantitative. The sampling technique is proportional random sampling with a sample of 152 people. The data analysis technique used in this study is the path analysis technique. The results showed that organizational culture positively affected work motivation, work satisfaction, and organizational citizenship behavior (OCB). Work motivation and job satisfaction have a positive effect on organizational citizenship behavior (OCB). Work motivation and job satisfaction have direct and indirect effects on Organizational Citizenship Behavior (OCB). With these results, the researcher recommends several things as a consideration in determining company policy. PT. National Capital Madani (PNM) should continue to improve employee motivation, especially work performance and achievement of job targets, as well as job satisfaction, can continue to be improved, especially aspects of work under educational background and salary, altruism and sportsmanship must be given more attention by the company.
\end{abstract}

Keywords: Organizational Culture, Job Satisfaction, Work Motivation, OCB.

\section{INTRODUCTION}

Human resources (HR) is one of the most critical factors that cannot be separated from an organization, either a company or an institution. In addition, HR is also a factor influencing the development of a company. In other words, a company can be said to develop very rapidly if there are competent human resources in their fields. Conversely, if the human resources working in a company are not qualified, then the company's development will be hampered. Resources that drive and direct the organization, human resources must always be considered, maintained, maintained, and developed by the organization [1]. Human resources are seen as a crucial element in organizational development because the development will be realized if supported by quality human resources [2] in page 65 .
Organizational culture is the basis that becomes a role model for all individuals who are in the organization and in carrying out its activities, both at work, socializing, and other activities inside and outside of work, so that all activities that take place are valuable and meaningful [3] on page 272. Reference [4] on page 124 defines organizational culture as a pattern of basic assumptions created, discovered, or developed by a particular group of people as they adjust to external and internal problems that have worked well enough and are considered valuable, and are taught to new members as a method of adaptation. Whereas reference [5] in page 165 suggested that organizational culture is a cognitive framework consisting of attitudes, values, norms of behavior, and shared expectations felt by the organization's members. 
Reference [6] in page 127 state that what is meant by motivation is a process that explains the strength, direction, and perseverance of someone to achieve goals. Motivation can be interpreted as the urge of individuals to take action because they want to do it. If the individual is motivated, the individual will make positive choices to do something because it can satisfy his desires reference [7] in page 837-838, Several studies have shown that highly motivated employees will do their jobs better. On this basis, motivation requires the intervention of company management [8].

Reference [9] define job satisfaction as a person's attitude towards work. This attitude results from a person's perception of his work, and there is a level of disagreement between employees as individuals and organizations. Meanwhile, according to [10] in page 193194 , job satisfaction is a pleasant or unpleasant emotional state in which employees view their work. Job satisfaction reflects one's feelings about their work. This is evident in the employee's positive attitude towards work and everything faced in the work environment. Work satisfaction is an effectiveness or emotional response to various aspects of work. A set of employees' feelings about pleasing or not their work. A general attitude towards one's work that shows the difference between the number of awards received by workers and the amount they believe they should receive [11] in page 58 .

Organizational Citizenship Behavior (OCB) is an individual contribution that goes deeper than the demands of the role at work and is rewarded by the acquisition of task performance. OCB involves several behaviors, including helping others, volunteering for extra tasks, complying with rules and procedures at work. These behaviors illustrate the added value for employees and are one form of prosocial behavior, namely positive, constructive and meaningful social behavior that helps [12] in page 1. Reference [13] notes that Organizational Citizenship Behavior (OCB) was found as an alternative explanation for the satisfaction hypothesis based on performance, and when individuals display good performance, it will affect organizational performance. Reference [14] on page 302, state that OCB is employee behavior that exceeds work-role requirements. Reference [5] on page 409-410, also mentioned that being a person with OCB has more important impacts than an effort to recruit. The more positive statements from existing employees about the company where they work, the more effective the company can recruit the best new employees. Therefore, although OCB's impact can be indirect and difficult to measure, OCB's presence can be very beneficial for the company.

\section{METHODS}

Data analysis techniques were used to see the influence of organizational culture $(\mathrm{X})$ on motivation
(Y1) and job satisfaction (Y2) and its impact on OCB (Z). This research used the path analysis technique. Path analysis is used to analyze the relationship between variables to find out whether direct or indirect influences exist between the independent variables (independent) of the dependent variable.

This research is quantitative research. The type of method used in sampling is the proportional random sampling method, a sample that is calculated based on comparison with random sampling. Characteristics of the sample used in this study are permanent employees of the company. The population size of 245 employees with a leeway level of $5 \%(0.05)$ or can be called an accuracy rate of $95 \%$ ( 0.95$)$ based on table 1 , so the sample taken to represent the population using the slovin technique is as follows:

$$
\begin{aligned}
n & =\frac{245}{1+245(0,05)^{2}} \\
n & =\frac{245}{1+0,6125} \\
& =\frac{245}{1,6125} \\
& =151,9=152
\end{aligned}
$$

The sample size was rounded up to 152 people, so based on calculations using the Slovin formula, the sample taken to be the respondent in this study was 152

\begin{tabular}{|c|c|c|c|c|c|}
\hline Model & $\begin{array}{c}\text { Path } \\
\text { coefficient }\end{array}$ & $\mathbf{t}$ & $\rho$ & $\mathbf{F}$ & $\mathbf{R}^{2}$ \\
\hline \multicolumn{6}{|c|}{ Model $1 \rightarrow Y_{1}=\rho Y_{1} X+\varepsilon_{1}$} \\
\hline $\begin{array}{l}X_{1} \\
\left(\rho Y_{1} X_{1}\right)\end{array}$ & 0.815 & 17.227 & 0.000 & 296.770 & 0.664 \\
\hline \multicolumn{6}{|c|}{ Model $2 \rightarrow Y_{2}=\rho Y_{2} X+\varepsilon_{2}$} \\
\hline $\begin{array}{l}X_{1} \\
\left(\rho Y_{2} X_{1}\right)\end{array}$ & 0.786 & 15.592 & 0.000 & 243.102 & 0.618 \\
\hline \multicolumn{6}{|c|}{ Model $3 \rightarrow Z=\rho Z X+\rho Z Y_{1}+\rho Z Y_{2}+\varepsilon_{3}$} \\
\hline$X(\rho Z X)$ & 0.377 & 4.358 & 0.000 & 100.325 & 0.670 \\
\hline $\begin{array}{l}\text { Y1 } \\
(\rho Z Y 1)\end{array}$ & 0.294 & 3.051 & 0.003 & & \\
\hline $\begin{array}{l}\mathrm{Y} 2 \\
(\rho \mathrm{YY} 2)\end{array}$ & 0.203 & 2.251 & 0.026 & & \\
\hline
\end{tabular}
people. The research instrument used in this study is in the form of a questionnaire.

Table 1. Model

\section{RESULTS AND DISCUSSION}

The influence of Organizational Culture on Work Motivation obtained $\beta$ value of 0.815 with a level of significance $\rho=0.05$ or $5 \%$, obtained from the same substructural equation the influence of $\mathrm{X}$ on $\mathrm{Y} 1$ as follow (1).

$$
\mathrm{Y}_{1}=\rho \mathrm{Y}_{1} \mathrm{X}_{1}+\varepsilon_{1}
$$

$\mathrm{Y}_{1}=0.815 \mathrm{X}_{1}+\varepsilon_{1}$ 
The equation means that the higher the organizational culture, the higher the employee's work motivation and vice versa. The direct influence of Organizational Culture on Work Motivation is positive and significant $\rho=0.05$ or $5 \%$, with tcount $>\mathrm{t}$ table $17.227>1.960$. the influence of organizational culture on the work motivation of 0.664 or $64.4 \%$. This means that organizational culture's influence on work motivation is $64.4 \%$, while other factors influence $35.6 \%$. In comparison, the magnitude of organizational culture's direct influence on work motivation is 0.815 or $81.5 \%$, while $18.5 \%$ is influenced by other factors outside the model. The direct influence of Organizational Culture on Job satisfaction is obtained $\beta$ value of 0.786 with a significance level $\rho=0.05$ or $5 \%$, which is obtained from the sub-structural equation two the influence of $\mathrm{X}$ on $\mathrm{Y} 2$ as follow (2).

$$
\begin{gathered}
Y_{2}=\rho Y_{2} X_{1}+\varepsilon_{2} \\
Y_{2}=0.786 X_{1}+\varepsilon_{2}
\end{gathered}
$$

From the equation to find out the direct effect, it can be seen that the $\mathrm{t}$-count is calculated and compared with the $\mathrm{t}$-table, then the $\mathrm{t}$-value obtained is $15,592>$ from the t-table of 1,960 or $15,592>1,960$. The magnitude of the influence of organizational culture on job satisfaction directly is equal to $61.8 \%$. Other factors outside the model influence the remaining $38.2 \%$. the value of $\beta$ is 0.377 with a significance level $\rho=0.05$ or $5 \%$, the value of $\mathrm{t}$-count $>\mathrm{t}$-table is $4.358>1.960$, which is obtained from structural equation as follow (3).

$$
\begin{gathered}
Z=\rho Z_{1} X_{1}+\rho Z_{1} Y_{1}+\rho Z_{1} Y_{2}+\varepsilon_{3} \\
Z=0.377 X_{1}+0.294 Y_{1}+0.203 Y_{2}+\varepsilon_{3}
\end{gathered}
$$

Based on the hypothesis test results where the $\beta$ value of 0.377 , with a significance level of $5 \%$, the value of $\rho$ $=0.000$ is obtained, the value of t-count $>\mathrm{t}$-table is $4.358>1.960$, it can be concluded that the hypothesis is accepted. Thus, it can be stated that organizational culture has a significantly positive effect on OCB. The magnitude of the direct influence of organizational culture on OCB is equal to $37.7 \%$. Other factors outside this model influence the rest.

$\beta$ value of 0.294 with a significance level $\rho=0.05$ or $5 \%$, the value of $\mathrm{t}$-count $>\mathrm{t}$-table is $3.0581>1.960$, which is obtained from structural equation (4).

$$
\begin{gathered}
Z=\rho Z_{1} X_{1}+\rho Z_{1} Y_{1}+\rho Z_{1} Y_{2}+\varepsilon_{3} \\
Z=0.377 X_{1}+0.294 Y_{1}+0.203 Y_{2}+\varepsilon_{3}
\end{gathered}
$$

Based on the hypothesis testing results, where the value of $\beta$ is $0.294, \rho=0.003$ with a significance level of $5 \%$, the value of $\mathrm{t}$-count $>\mathrm{t}$-table is $4.358>1,960$. It can be concluded that there is an influence between work motivation on Organizational Citizenship Behavior ( OCB). The magnitude of the direct influence of work motivation on OCB is $29.4 \%$, and other factors outside this model influence the rest. The hypothesis test results mean that the higher the work motivation, the higher the OCB level of employees.

To test the effect of job satisfaction on Organizational Citizenship Behavior (OCB), the results of the hypothesis test show that a $\beta$ value of 0.203 with a significance level of $5 \%$ is obtained $\rho=0.026$, a t-test value $>\mathrm{t}$-table is $3.0581>1.960$, obtained from structural equation (5).

$$
\begin{gathered}
Z=\rho Z_{1} X_{1}+\rho Z_{1} Y_{1}+\rho Z_{1} Y_{2}+\varepsilon_{3} \\
Z=0.377 X_{1}+0.294 Y_{1}+0.203 Y_{2}+\varepsilon_{3}
\end{gathered}
$$

Based on the hypothesis test results, it means that the higher employee job satisfaction, the higher the OCB level of the employee. Based on the results of hypothesis testing, it can be concluded that job satisfaction has a significant positive effect on Organizational Citizenship Behavior (OCB). The magnitude of the direct effect of job satisfaction on OCB is 20.43. The rest is influenced by other factors outside this model.

Table 2. The Indirect Effect of Organizational Culture on Organizational Citizenship Behavior (OCB) at the Office of PT.PNM Garut Branch

\begin{tabular}{|c|l|l|l|l|}
\hline $\begin{array}{c}\text { Model } \\
\text { Pathways }\end{array}$ & $\begin{array}{c}\text { Indirect } \\
\text { effect(s) } \\
\text { of X on Z: }\end{array}$ & z_hit & $\begin{array}{c}\text { z_tab } \\
\text { el }\end{array}$ & ket \\
\hline $\begin{array}{c}\text { Total Indirect } \\
\text { effect }\end{array}$ & 0.398 & & & \\
\hline Indirect effect 1 & 0.239 & $\begin{array}{l}3.009 \\
8\end{array}$ & 1.98 & $\begin{array}{l}\text { Significa } \\
\text { nt }\end{array}$ \\
\hline Indirect effect 2 & 0.159 & $\begin{array}{l}2.242 \\
0\end{array}$ & 1.98 & $\begin{array}{l}\text { Significa } \\
\text { nt }\end{array}$ \\
\hline & \multicolumn{3}{|c|}{ Model } \\
\hline Indirect effect 1 & BO -> MO $>$ OCB \\
\hline Indirect effect 2 & BO -> KK $>$ OCB \\
\hline
\end{tabular}

The value of the total indirect effect of organizational culture influence on OCB through work motivation is 0.239 . To determine whether there is an indirect influence of organizational culture on OCB, the Sobel test was done [15]. The results of the Sobel test (z) are presented in table 4.13. Based on table 4.13 obtained the value of $\mathrm{Z}$-count $>\mathrm{Z}$-table or 3.0098>1,980 with a significance level of $5 \%$. Thus, it can be concluded that there is an indirect influence between cultures organization of OCB through work motivation or work motivation mediating the influence of organizational culture on OCB. The indirect influence of Organizational Culture on OCB through Job Satisfaction obtained the value of $\mathrm{Z}$-count $>\mathrm{Z}$-table or $2.2420>1,980$ with a significance level of $5 \%$, the total indirect effect of 0.159 . Thus it can be concluded that there is an indirect effect between organizational culture towards OCB through job 
satisfaction or job satisfaction mediates the influence of organizational culture on OCB.

\section{CONCLUSIONS}

The results of the study found that organizational culture directly influences Organizational Citizenship Behavior (OCB). This study indicates that employees who have strong organizational culture encourage the formation of high Organization Citizenship Behavior (OCB) behavior, namely the behavior of extreme roles and behavior formed outside the job description. However, a weak organizational culture tends to be challenging to form the expected OCB because organizational culture is a significant factor in creating OCB. According to [16], organizational culture is an initial condition that can encourage OCB to occur to employees. The results of this study indicate that quality organizational culture will lead to high OCB Behavior.

The study result found work motivation has a direct influence on OCB. It indicated that employees who have high work motivation have good citizenship behavior (OCB). Employees who have good work motivation can do the work better than before, always wanting to complete challenging work and get the job done on time. A good motivation is a driving factor for the employee concerned to continue to develop themselves. This selfdevelopment encourages employees to excel. Following Mc Clelland's motivation theory, motivation is under the strength of one's need for achievement. The higher the motivation of a person, the higher the possibility of achievement by that person.

High work motivation can shape each employee has OCB values that are implemented in organizational life. The results of this study indicate that employees of PT. Capital Manadani has an excellent level of work motivation; five factors increase employee work motivation, namely: work baggage, achievement, recognition, and a sense of security. The five factors above are essential and must be continuously developed by the organization because these five factors in this study are the main factors that can increase employee motivation. This work motivation impacts the OCB level of employees, which is indicated by the increase in OCB behavior in the organization.

This study found that there is an influence of organizational culture on work motivation, job satisfaction, and OCB. The results also found that work motivation and work satisfaction have an indirect effect on OCB. The results of this study indicate that OCB formed in each member of the organization is highly determined by organizational cultural values that encourage work motivation and job satisfaction high employee, conversely lower job satisfaction and lack of motivation to actively participate in organizational activities having poor organizational citizenship behavior
(OCB) [17]. Job satisfaction and work motivation are formed due to a healthy organizational culture, which can shape the organizational citizenship attitude (OCB) expected by the organization, namely employees who can work optimally (extra roles) outside their duties. These OCB attitudes ultimately will support organizational performance. Companies that have employees with high OCB have good organizational performance.

\section{REFERENCES}

[1] J. Pfeffer and G. R. Salancik, "The external control of organizations: a resource dependence perspective," Stanford University Press, 2003. .

[2] N. H. Tangkilisan, "Manajemen publik," PT. Gramedia Widiasarana Indones., 2005.

[3] T. Duha, Perilaku organisasi. Yogyakarta: Deepublish, 2016.

[4] F. Luthans, "Perilaku organisasi, edisi sepuluh," PT. Andi Yogyakarta., 2006.

[5] J. Greenberg and R. . Baron, Behavior in organazations understanding and managing the human side of work, Eighth. New Jersey: PreticeHall International.

[6] S. P. Robbins and T. A. Judge, Organizational behavior fifteenth edition. 2013.

[7] R. Veithzal and E. J. Sagala, Manajemen dumber daya manusia untuk organisasi dari teori ke praktik. Jakarta: PT Raja Grafindo, 2009.

[8] M. A. Gibson and E. Gurmu, "Rural to urban migration is an unforeseen impact of development intervention in ethiopia," PLoS One, vol. 7, no. 11, 2012, doi: 10.1371/journal.pone.0048708

[9] J. M. Ivancevich, R. Konopaske, and M. T. Matteso, Perilaku dan manajemen organisasi, 1 st \& 2 nd ed. Jakarta: Erlangga, 2008.

[10] T. H. Handoko, Manajemen personalia dan sumber daya manusia, edisi kedua. 2001.

[11] P. Afandi, Concept \& indicator human resources management for management research. Yogyakarta: Deepublish, 2016.

[12] R. Aldag and W. Reschke, "Employee value added: measuring discretionary effort and its value to the organization," Cent. Organ. Eff. Inc, 1997.

[13] D. W. Organ, “Organizational citizenship behavior: it's construct clean-up time," Hum. Perform., vol. 10, no. 2, 1997, doi: 10.1207/s15327043hup1002_2.

[14] R. Kreitner and A. Kinicki, “Organizational behavior: an interdisciplinary field," in Organizational Behavior, 2007. 
[15] I. Ghozali, "Aplikasi analisis multivariate dengan program IBM SPSS 19," Penerbit, . Semarang: Badan Diponegoro, Universitas, 2011. https://digilib.undip.ac.id/v2/2012/10/03/aplikasianalisis-multivariate-dengan-program-spss/.

[16] D. W. Organ and A. Lingl, "Personality, satisfaction, and organizational citizenship behavior," J. Soc. Psychol., vol. 135, no. 3, 1995, doi: 10.1080/00224545.1995.9713963.

[17] S. A. Gyekye and M. Haybatollahi, “Organizational citizenship behavior: an empirical investigation of the impact of age and job satisfaction on Ghanaian industrial workers," Int. J. Organ. Anal., vol. 23, no. 2, 2015, doi: 10.1108/IJOA-08-2012-0586. 